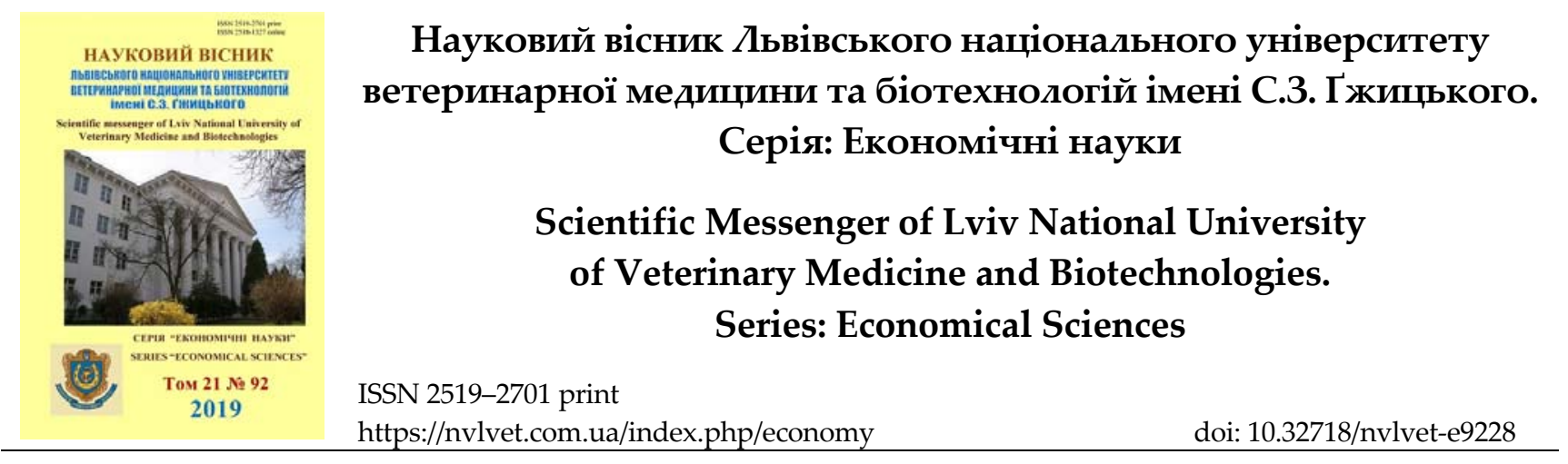

UDC 613.164

\title{
Noise pollution is one of the causes of occupational diseases
}

\author{
I.G. Yaroshovych, B.P. Tchaikovskyj, B.M. Mykychak, T.S. Yaroshovych \\ Stepan Gzhytskyi National University of Veterinary Medicine and Biotechnologies, Lviv, Ukraine
}

Article info

Received 04.02.2019

Received in revised form 06.03 .2019

Accepted 07.03.2019

Stepan Gzhytskyi National University of Veterinary Medicine and Biotechnologies Lviv, Pekarska Str., 50, Lviv, 79010, Ukraine.

Tel.: +38-050-225-08-71 E-mail:kantsvetlv@i.ua
Yaroshovych, I.G., Tchaikovskyj, B.P., Mykychak, B.M., \& Yaroshovych, T.S. (2019). Noise pollution is one of the causes of occupational diseases. Scientific Messenger of Lviv National University of Veterinary Medicine and Biotechnologies. Series: Economical Sciences, 21(92), 165168. doi: 10.32718/nvlvet-e9228

People lose hearing more often than we can imagine. Loss of hearing or deafness today is one of the most common occupational diseases not only in Ukraine but also in the world. Every day we are accompanied by a whole range of the most diverse sources of noise - household appliances at home and in the office, neighbors repairs, televisions, the road to work - metro, people in public transport or loud headphones music. And this can not be avoided, because each of us lives in a society, co-exists with other its representatives. All our life - a global communication. Many experiments found that noise is a general biologic stimulus and under certain conditions can affect all human life systems. The influence of noise on the human auditory organ is most fully studied. Intense noise, especially at high frequencies $-4000 \mathrm{~Hz}$ or more, with daily exposure leads to a professional illness - hearing loss, the symptom of which is the slow loss of hearing on both ears. According to official statistics of the World Health Organization, more than 5\% of the Earth's population suffers from a disabling hearing loss. That is, such loss results not only in the deterioration of hearing quality, but also has certain social consequences, namely:

- more than 360 million people around the world have hearing problems (about 328 million adults and 32 million children);

- 1.1 billion teenagers and young people are at risk of hearing loss mainly due to listening to highvolume music as well as excessive noise levels;

- more than a third of people lose hearing as a result of excessive noise levels in the workplace. The rest is congenital deafness, loss of hearing due to various diseases and injuries;

- an average of almost ten years is passed before hearing impaired people turn to a doctor;

- studies have shown that about 1/3 of people over 65 years have hearing problems.

Key words: worker, person, noise, noise pollution, hearing, deafness.

\section{Шумове забруднення одне з причин професійних захворювань}

\author{
І.Г. Ярошович, Б.П. Чайковський, Б.М. Микичак, Т.С. Ярошович
}

Львівський національний університет ветеринарної медицини та біотехнологій імені С.3. Гжицького, м. Львів, Украӥна

\footnotetext{
Люди втрачають слух частіше, ніж ми можемо собі уявити. Втрата слуху або приглухуватість сьогодні є одним з найпоширеніших професійних захворювань не тільки в Украӥні, але й у світі. Кожного дня нас супроводжує ијіла палітра найрізноманітніших за походженням шумів - побутові прилади вдома та в офісі, ремонти сусідів, телевізори, дорогою на роботу -метро, люди у громадському транспорті або гучна музика з навушників. I иььоо не уникнути, адже кожен із нас живе у суспільстві, співіснує з іншими його представниками. Все наме життя - ие глобальна комунікачія. Багатьма дослідами встановлено, шо шум є загальнобіологічним подразником і в певних умовах може впливати на всі системи життєдіяльності людини. Найповніше вивчено вплив шуму на слуховий орган людини. Інтенсивний шум, особливо за високих частот - 4000 Ги і більше, при щоденному впливі призводить до виникнення професійного захворювання - тугоухості, симптомом якого є повільне втрачання слуху на обидва вуха. Згідно з офічійною статистикою Всесвітньої організачї охорони здоров'я, більше ніж 5\% населення Землі страждає від інвалідизуючої втрати слуху. Тобто така втрата призводить не тільки до погіршення якості слуху, але й має певні сочіальні наслідки, а саме:
} 


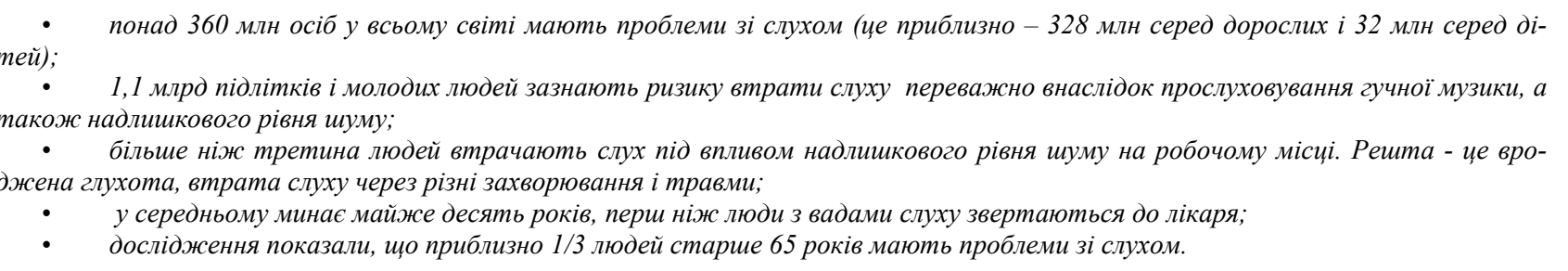

Ключові слова: працівник, людина, иум, шумове забруднення, слух, глухота.

Виділяють природні та штучні причини зниження якості слуху або повної його втрати. У випадку природних причин перш за все мова йде про погіршення слуху, пов'язане з віковими змінами в організмі людини, а саме - $з$ атрофією чуттєвих слухових клітин у завитку внутрішнього вуха.

У випадку штучних причин така атрофія відбувається набагато швидше, а іноді й миттєво. Головним штучним шкідливим фактором та причиною зниження якості або втрати слуху є шумове забруднення (Zhydetskyi, 2005).

Наукова громада усього світу вже визнала негативний вплив шуму на здоров'я людини. Все більшого поширення нині набуває термін “шумове забруднення”. Шумове забруднення - це форма фізичного забруднення, що полягає у збільшенні рівня шуму понад природний, викликає у людини за короткочасного впливу - неспокій, а за тривалого - погіршення здоров'я. Не варто применшувати дію шумового забруднення. За даними австрійських вчених, "шумове забруднення”, яке є невід'ємною частиною будь-якого великого міста, скорочує тривалість життя людини на 10-12 років (Chaikovskyi et al., 2013; Fandieiev, 2016).

Серед факторів зовнішнього середовища, що впливають на організм людини в процесі праці, шумове забруднення і вібрація займає одне з перших місць.

Шкідливий та небезпечний вплив шумового забруднення на організм людини встановлено тепер 3 повною достовірністю. Ступінь такого впливу, переважно, залежить від рівня та характеру шуму, форми та тривалості впливу, а також індивідуальних особливостей людини. Численні дослідження підтвердили той факт, що шумове забруднення належить до загально фізіологічних подразників, які за певних обставин можуть впливати на більшість органів та систем організму людини. Так, за даними медиків дія шумового забруднення може спричинити нервові, серцевосудинні захворювання, виразкову хворобу, порушення обмінних процесів та функціонування органів слуху тощо.

Шумове забруднення також впливає безпосередньо на різні відділення головного мозку, змінюючи нормальні процеси вищої нервової діяльності. Цей вплив може негативно позначитися навіть раніше, ніж виникнуть проблеми із сприйняттям звуків органами слуху. Характерним впливом шуму є скарги на підвищення втомлюваності, загальну слабкість, роздратування, апатію, послаблення пам'яті, пітливість та інші нездужання. Практикою встановлено також вплив шуму на органи зору людини - зниження гостроти зору та зниження чутливості розрізнення кольо- рів. Страждає від шуму також вестибулярний апарат, порушуються функції шлунково-кишкового тракту, підвищується внутрішньочерепний тиск, порушуються процеси обміну в організмі та ін.

Шум, особливо непостійний (коливальний, переривчастий, імпульсний погіршує здатність до виконання точних робочих операцій, утруднює сприйняття інформації. Всесвітня організація охорони здоров'я (BOO3) відзначає, що найбільш чутливими до впливу шуму $є$ такі операції, як збір інформації, складання і мислення.

Несприятливий вплив шуму на працівника призводить до зниження продуктивності праці, створюються передумови для виникнення нещасних випадків та аварій. Все це визначає велике економічне і оздоровче значення заходів по боротьбі з шумом. У виробничих умовах часто шум має непостійний характер. Для цих умов найбільш зручно застосовувати середні величини, які звуться еквівалентним (по енергії) рівнем звуку Б що характеризує середнє значення енергії звуку в дБ. Цей рівень вимірюється спеціальним інтегруючим шумоміром або розраховується математичним методом.

Звукові хвилі, що поширюються в повітрі, долають непростий шлях, перш ніж ми їх сприймемо. Спочатку вони проникають у вушну раковину і змушують вібрувати барабанну перетинку, що закриває зовнішній слуховий прохід. Слухові кісточки доносять ці коливання до овального вікна внутрішнього вуха. Плівка, що закриває це вікно, передає вібрації рідині, яка наповнює завитку. Нарешті коливання доходять до слухових клітин внутрішнього вуха (Shostak, 2017).

Головний мозок сприймає ці сигнали і розпізнає в них шуми, звуки, музику, мову. Надмірний шум пошкоджує чутливі волоскові клітини завитки. Цей процес незворотний, оскільки такі клітини не відновлюються.

Існує зв'язок між рівнем шуму (гучністю), часом впливу і швидкістю пошкодження слуху. Наприклад, якщо було встановлено, що працівник дістав пошкодження слуху в результаті впливу звуку гучністю 85 дБ через 8 год, то підвищення рівня гучності тільки на 3 дБ, до 88 дБ, завдасть такої самої шкоди за 4 год, а ще на 3 дБ, до 91 дБ, - усього за 2 год. Нескладно підрахувати, що при досягненні 95 дБ достатньо лише 15 хв, щоб заподіяти слуху таку саму шкоду. Початковий рівень гучності 80 дБ зріс тільки на 15 дБ, а результат уже настільки драматичний. Нарешті, при досягненні больового порогу людини в 130-140 дБ такої самої шкоди слуху буде завдано менш ніж за 1 секунду. 
Ці розрахунки демонструють, як незначне підвищення рівня гучності призводить до надзвичайно небезпечного впливу на слух людини і чому ми повинні контролювати вплив звуку на нас.

Наслідки впливу високого рівня гучності на людину можуть проявлятися шумом у вухах - тінітусом, втратою слуху або іншими проблемами зі здоров'ям.

Тінітус часто описують як дзвеніння, дзижчання або гудіння у вухах за відсутності зовнішнього звуку. Тінітус виникає через низку причин, зокрема пошкодження кровоносних судин, побічні ефекти від при-

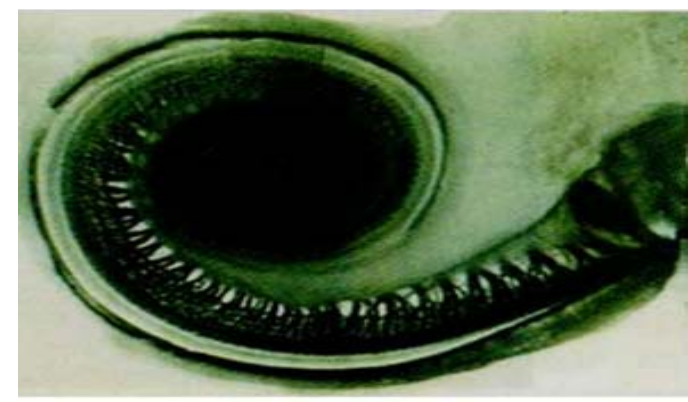

Рис. 1. Вушна завитка здорової людини

Із загальної кількості захворювань, що перераховані вище, останнім часом значно зросла частка тих, які спричинені саме шумовим впливом. У зв'язку 3 цим слід звернути увагу на той факт, що протягом багатовікової еволюції людина так і не набула здатності адаптуватись до дії шуму, як і не було створено природного захисту для високочутливого та досконалого органу слуху людини від дії інтенсивного шуму.

Медики відзначають особливо несприятливу дію навіть незначних за рівнем шумів у години відпочинку i, передовсім, сну, коли найбільш повно повинні відновлюватись сили людини. Не зайве нагадати, що у зв'язку з вищезазначеним у нашій країні, як і у багатьох інших, діє заборона щодо порушення тиші у житлових масивах з 23.00 до 7.00 години ранку 45 дБ, а у квартирах 30-40 дБ.

Найбільш повно вивчено вплив шуму на слуховий апарат людини. У працівників “шумних" професій може виникнути професійне захворювання - туговухість, основним симптомом якого є поступова втрата слуху, перш за все, в ділянці високих частот, з наступним поширенням на більш низькі частоти.

Крім безпосереднього впливу на орган слуху, шум впливає на різні відділи головного мозку, змінюючи при цьому нормальні процеси вищої нервової діяльності. Цей так званий неспецифічний вплив шуму може виникнути навіть раніше, ніж зміни в самому органі слуху. Характерними є скарги на підвищену втомлюваність, загальну слабкість, роздратованість, апатію, послаблення пам'яті, погану розумову діяльність і т. ін.

Наближено дію шуму різних рівнів можна схарактеризувати наступним чином. Шум до 50 дБ зазвичай не чинить шкідливого впливу на людину в процесі іiі трудової діяльності. Шум у 50-60 дБ може мати психологічний вплив, що виявляється у погіршенні розу- йому ліків, хворобу та стрес. Але найпоширенішою причиною є дія гучного шуму, що завдає шкоди слуxy.

Постійна втрата слуху - це результат надмірного впливу “небезпечного" шуму, який відчувається зазвичай через деякий час. Як було зазначено раніше, відбувається поступове пошкодження волоскових клітин у завитці, у результаті чого знижується чутливість до певних звукових частот. Зрештою, пошкоджені волоскові клітини відмирають, і через те, що вони не відновлюються, настає повна глухота.

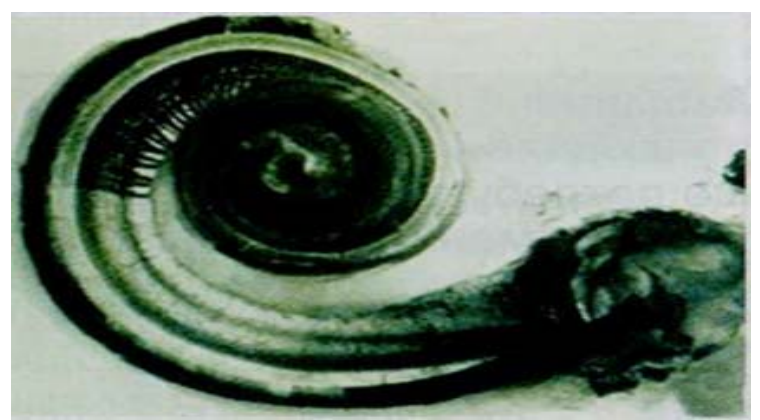

Рис. 2. Вушна завитка людини, яка постійно зазнає шумового впливу

мової діяльності, послабленні уваги, швидкості реакції, утрудненні роботи 3 сприйняттям інформації тощо. При рівні шуму 65-90 дБ можливий його фізіологічний вплив: пульс пришвидшується, тиск крові зростає, судини звужуються, що погіршує постачання органів кров'ю. Дія шуму з рівнем 90 дБ і вище може призвести до функціональних порушень в органах та системах організму людини: знижується слухова чутливість, погіршується діяльність шлунку та кишківника, з'являється відчуття нудоти, головний біль, шум у вухах. При рівні шуму 120-160 дБ та вище здійснюється механічний вплив на орган слуху, що виявляється у порушенні зв'язків між окремими ділянками внутрішнього вуха; можливий навіть розрив барабанної перетинки. Такі високі рівні шуму впливають не лише на органи слуху, а й на весь організм. Звукові хвилі, проникаючи крізь шкіру, спричинюють механічні коливання тканин організму, внаслідок чого відбувається руйнування нервових клітин, розриви барабанних перетинок і легень, а 200 дБ - призводить до смерті.

Високі рівні шумів також є одним із основних шкідливих факторів в умовах сучасних промислових виробництв. Згідно $з$ вимогами законодавства, якщо рівень будь-яких шумів на виробничому місці перевищує 85 дБ, носіння засобів індивідуального захисту (3ІЗ) органів слуху є обов'язковим.

Еволюція цих засобів доволі проста. Спершу для захисту від шуму люди інтуїтивно затуляли вуха долонями. Але руки не завжди вільні, та й такого захисту недостатньо. Пізніше для захисту використовували вату. Можна пригадати безліч аматорських винаходів людей, але все ж таки краще звернути увагу на професійні досягнення сучасності.

Нині є два найефективніших засоби захисту слуху: протишумові вкладки й навушники. Донедавна ці $3 \mathrm{I3}$ 
слуху були тільки так званим пасивним захистом, тобто просто знижували рівень шуму на певну кількість децибелів. А людина, яка перебувала в умовах шуму, захищаючи себе за допомогою навушників або протишумових вкладишів, відчувала деякі незручності. Перша проблема полягала в неможливості ефективно спілкуватися з колегами. Друга - в неможливості почути будь які попереджувальні сигнали про виробничу небезпеку.

Зараз обидві ці проблеми можна вирішити, використовуючи нові розробки у сфері 3І3 слуху: активні й комунікаційні навушники.

Активні навушники - це ідеальне рішення в умовах підвищеного шуму, коли людині потрібно чути, що відбувається навколо, і спілкуватися. Функція активного захисту полягає в тому, що електронне обладнання навушників із вбудованими стереомікрофонами аналізує інформацію і підсилює слабкі звуки. У такий спосіб їх чути навіть краще, ніж без активних навушників.

Різкі імпульси небезпечного шуму, які перевищують поріг 82 дБ, негайно заглушуються, що захищає працівника від надмірного шуму. Це дає змогу чути все, що відбувається навколо (зокрема, попереджувальні сигнали машин, механізмів тощо), і в такий спосіб уникнути почуття ізоляції від навколишнього світу.

Комунікаиійні навушники - дають можливість працівнику в умовах шуму спілкуватися 3 колегами на великій відстані. Завдяки безперервній комунікації підвищується ефективність і швидкість виконання операцій. Якщо обладнання на виробництві з якоїсь причини перестає працювати, співробітник, маючи постійний зв'язок із колегами, може швидко вирішувати проблеми, що виникають. До того ж комунікаційні навушники зберігають не тільки слух, а й життя людей завдяки наявності постійного чіткого зв'язку.

Найпростіший варіант таких навушників - це стандартні гарнітури, які можна підключати до вже наявних на підприємстві рацій. У такий спосіб працівник постійно захищений від шуму і має змогу спілкуватися з колегами по рації в умовах підвищеного шуму.
Нині на ринку вже є навушники із вбудованою рацією. Плюси цієї комфортної компактної бездротової системи в тому, що в працівника вільні руки, адже йому не потрібно тримати рацію.

\section{Висновки}

Якщо засоби індивідуального захисту органів слуху використовують неправильно, без достатньої щільності прилягання, то й рівень захисту знижується у геометричній прогресії. Крім того, у кожної людини форма слухового каналу $є$ індивідуальною та унікальною. Тому, на жаль, не існує універсального захисту органів слуху, який був би однаково комфортним та ефективним для всіх.

Отже, шкідливі та небезпечні наслідки дії шуму виявляються тим більше, чим вищий рівень сили звуку та триваліша його дія. У структурі професійних захворювань перше місце належить хворобам органів дихання - 40,1\% від загальної кількості діагнозів по Україні (1228 випадків). На другому місці - захворювання опорно-рухового апарату (радикулопатії, остеохондрози, артрити, артрози) - 30\% (917 випадків). Третє місце за хворобами слуху - 10,3\% (316 випадків), четверте за вібраційною хворобою - 8,6\% (262 випадки).

\section{References}

Zhydetskyi, V.Ts. (2005). Osnovy okhorony pratsi. L.: Afisha (in Ukrainian).

Fandieiev, O. (2016). Shumova karta proty "povilnoho vbyvtsi" Naukovo-vyrobnychyi zhurnal Okhorona pratsi, 6, 42 (in Ukrainian).

Chaikovskyi, B.P., Yaroshovych, I.H, Shalko, A.V., Pavlyk, N.I., Zanichkovska, L.V., \& Yaroshovych, T.S. (2013). Metodychni vkazivky dlia provedennia laboratornykh zaniat $\mathrm{z}$ normatyvnoi dystsypliny "Osnovy okhorony pratsi" na temu "Shumove zabrudnennia i vibratsiia”. Lviv, 43 (in Ukrainian).

Shostak, M. (2017). Yakymy maiut buty ZIZ slukhu. Naukovo-vyrobnychyi zhurnal Okhorona pratsi, 6, 46 (in Ukrainian). 